\title{
Antibacterial activity of crude extracts of marine invertebrate Polyclinum madrasensis Sebastian
}

\section{K. Natarajan ${ }^{1}$, R. Sathish ${ }^{2}$, T. Regupathi ${ }^{3}$ and A. Riyaz ${ }^{1}$}

${ }^{1}$ Dept. of Pharmaceutical Biotechnology, Ultra College of Pharmacy, 4/235, Thasildhar nagar, Madurai-625020, India

${ }^{2}$ Dept. of Pharmacology; ${ }^{3}$ Dept. of Pharmaceutics, Ultra College of Pharmacy, Madurai-625020, India

nata14@rediffmail.com

\begin{abstract}
Antibacterial activity of methanol, hexane and petroleum ether extracts of Polyclinum madrasensis was evaluated by cup plate method against various clinical isolates. Two different concentrations $(1 \& 4 \mathrm{mg} / \mathrm{ml})$ were analyzed. Methanolic extract of $P$. madrasensis demonstrated high degree of activity against all tested bacterial isolates in increasing concentrations, whereas hexane extract showed good activity against gram negative pathogens in high concentration and moderate against gram positive pathogens in lower concentration. All strains were resistant to Pet ether extract in both the concentrations when compared to the standard (ciprofloxacin) used. The MIC and MBC for methanolic extract tested in study inferred that the values range between $0.70-0.95 \mathrm{mg} / \mathrm{ml}$ and $0.85-1.1 \mathrm{mg} / \mathrm{ml}$ respectively. It was concluded from the study that methanolic extract of $P$. madrasensis exhibits potential antibacterial property.
\end{abstract}

Keywords: Antimicrobial activity; Polyclinum madrasensis; cup plate method; clinical isolates.

\section{Introduction}

Ocean has potent bioactive compounds isolated from marine organisms which are currently used as food. A large proportion of natural compounds have been extracted from marine invertebrates, especially sponges, ascidians, bryozoans and mollusks and some of them are currently in clinical trials (Proksch et al., 2002). Ascidians are marine invertebrates which ranks second with promising source of drugs (Azumi et al., 1990). Most of the ascidians are utilized as such as food in various countries and they are known to produce bioactive metabolites which prevent bio-fouling and this can be considered as a kind of autogenic protection (Bergquist et al., 1978). This mechanism has proved to be timely alternative natural medicine to human beings. From tunicate (ascidians) Trididemnum solidum, the first marine compound entered human cancer clinical trial as a purified natural product (Carte, 1996), but was unsuccessful in further trials (Davidson, 1993). Already various ascidians such as Botryllus sp., Didemnum $S p$. were proved for producing anti cancer drugs (Azumi et al., 1990). Halocyamine A, an antimicrobial substance was isolated from haemocytes of the solitary ascidians Halocynthia roretzi (Azumi et al., 1990). The bioactive substance which possesses potent anticancer activity Ecteinascidin-743 was isolated from Caribbean Sea

Table 1. Antibacterial activity of $P$. madrasensis

\begin{tabular}{|l|c|c|c|c|c|c|c|c|c|}
\hline & \multicolumn{8}{|c|}{ Diameter of the inhibitory zone (mm) } \\
\cline { 2 - 11 } & $\begin{array}{c}\text { Conc. } \\
(\mathrm{mg} / \mathrm{ml})\end{array}$ & $\begin{array}{c}E . \\
\text { coli }\end{array}$ & $\begin{array}{c}K . \\
\text { pneu } \\
\text { monia }\end{array}$ & $\begin{array}{c}S . \\
\text { aureus }\end{array}$ & $\begin{array}{c}S . \\
\text { pneumo } \\
\text { nia }\end{array}$ & $\begin{array}{c}P . \\
\text { vulga } \\
\text { ris }\end{array}$ & $\begin{array}{c}P . \\
\text { aerugi } \\
\text { nosa }\end{array}$ & $\begin{array}{c}S . \\
\text { typhi }\end{array}$ & $\begin{array}{c}S . \\
\text { dysent } \\
\text { rica }\end{array}$ \\
\hline Pet.ether & 1 & - & - & - & - & 3 & - & 3 & - \\
\hline Pet.ether & 4 & 4 & 5 & 4 & 4 & 5 & 5 & 5 & 5 \\
\hline Hexane & 1 & 11 & 13 & 9 & 8 & 11 & 12 & 14 & 11 \\
\hline Hexane & 4 & 18 & 20 & 11 & 12 & 17 & 20 & 20 & 17 \\
\hline Methanol & 1 & 15 & 13 & 14 & 12 & 11 & 18 & 19 & 15 \\
\hline Methanol & 4 & 24 & 20 & 23 & 24 & 26 & 22 & 26 & 23 \\
\hline $\begin{array}{l}\text { Cipro- } \\
\text { floxacin }\end{array}$ & 1 & 30 & 25 & 18 & 21 & 25 & 24 & 23 & 22 \\
\hline
\end{tabular}

${ }^{*}$ All the values are mean of triplicates.

Research communication

CIndian Society for Education and Environment (iSee) squirt Ecteinascidia turbinate (Russo et al., 2008). Such potential Ascidians need to be explored for the pharmaceutical purpose. In view of this, our aim of study is to determine the antibacterial activity of various extracts of ascidians, collected from eastern coast of Tamil Nadu, India.

\section{Materials and methods}

Specimens were collected in the Gulf of Mannar region by engaging scuba divers (2 to $5 \mathrm{~m}$ depth) from rocks under sea. Samples were narcotized using menthol crystals and stored in 5\% formalin solution until identification and experimental work. Identification was done by renowned scientist and voucher specimen (AS2183) was deposited in A.P.C. Mahalaxmi college for women, Tuticorin. Samples were dried at $50^{\circ} \mathrm{C}$ pulverized into 40-mesh size.

The dried powdered sample $(100 \mathrm{~g})$ was cold macerated with pet ether $(200 \mathrm{ml})$ followed by hexane $(200 \mathrm{ml})$ and methanol $(200 \mathrm{ml})$ each $24 \mathrm{~h}$. The solvents were evaporated to dryness (Seleghim et al., 2007). Obtained residual yields were $15 \% \mathrm{w} / \mathrm{w}$ for pet ether, $7.05 \% \mathrm{w} / \mathrm{w}$ for hexane and $9 \% \mathrm{w} / \mathrm{w}$ for methanol. Escherichia coli, Klebsiella pneumonia, Staphylococcus aureus, Streptococcus pneumoniae, Proteus vulgaris, Pseudomonas aeruginosa, Salmonella typhi and Shigella dysenteriae were collected from Bose clinical laboratory, Madurai and characterized. The clinical isolates were subcultured from stock culture $24 \mathrm{~h}$ prior to the experiment in nutrient agar media and used for the study. Nutrient Agar, Muller Hinton agar and Ciprofloxacin were procured from Himedia. All three extracts of Polyclinum madrasensis were tested for antibacterial activity by cup plate method (Hugo \& Russell, 2004); Muller

"Antibacterial activity of Polyclinum madrasensis" http://www.indjst.org
Natarajan et al. Indian J.Sci.Technol. 
Hinton agar media were prepared and sterilized in an autoclave and $10 \mathrm{ml}$ transferred to previously sterilized petriplates. After solidification petriplates were inoculated with $E$. coli, $K$. pneumonia, $S$. aureus, $S$. pneumoniae, $P$. vulgaris, $P$. aeruginosa, $S$. typhi and $S$. Dysenteriae under aseptic conditions. Ciprofloxacin was used as standard drug. Using a sterile borer, four wells were made and control vehicle (dimethyl formamide), test drug (two conc.) and standard drug (ciprofloxacin) were poured aseptically into the wells. The plates were incubated at $37^{\circ} \mathrm{C}$ for $18 \mathrm{~h}$. The zone of inhibition was measured using a metric ruler. Minimum inhibitory concentration was determined by the following procedure. Various concentrations of the methanolic crude extracts of $P$. madrasensis ranging from $0.50-1.25 \mathrm{mg} / \mathrm{ml}$ were introduced into different test tubes, each tube was inoculated with an overnight culture of strains diluted to give a final concentration of $10^{6} \mathrm{cell} / \mathrm{s} / \mathrm{ml}$. The tubes were incubated at $37^{\circ} \mathrm{C}$ for $24 \mathrm{~h}$ (Collins et al., 1995). Minimum bactericidal concentration was experimented after the MIC in freshly prepared agar plates. After culturing the test organisms separately in nutrient broth containing various concentrations of the active ingredients, the broth was inoculated onto freshly prepared agar plates to assay for the bactericidal effect. The culture was incubated at $37^{\circ} \mathrm{C}$ for $24 \mathrm{~h}$. The lowest concentration of extract that does not yield any colony growth on the solid medium after the incubation period was regarded as minimum bactericidal concentration (MBC) (Alade \& Irobi, 1995).

\section{Results and discussion}

Antimicrobial activity of two different concentrations of three extracts of Polyclinum madrasensis has been evaluated in vitro against gram positive and negative bacteria that are isolated from infected patients (Table 1). Its inhibitory effect was proportional to concentration gradient. Kurosaki and Nishi (1983) reported that higher concentrations of antimicrobial substances showed appreciable growth inhibition to microorganisms and this study complies with the statement. Methanolic extract of $P$. madrasensis demonstrated high degree of activity against all tested bacterial isolates whereas hexane extract showed good activity against gram-negative pathogens and moderate against gram-positive pathogens. All strains were resistant to petroleum ether extract showing very minimal zone of inhibition.

The minimum inhibitory concentrations (MICs) and Minimum bactericidal concentration (MBC) of the methanolic extract of $P$. madrasensis are shown in Table 2. The range of MIC varied between $0.70-0.95 \mathrm{mg} / \mathrm{ml}$ against all the bacterial strains used in this study and MBC ranges between $0.85-1.10 \mathrm{mg} / \mathrm{ml}$ against all the bacterial clinical strains. Ascidians are already reported
Vol. 3 No. 3 (Mar 2010)

ISSN: 0974- 6846 for rich nitrogenous source with a wide range of biological activities (Biard et al., 1994). The present investigation shows the broad spectrum antibacterial activity of Ascidian and this may be due to the nitrogenous bioactive principles which need to be determined in future. Conclusion

The methanolic extract has significant inhibitory effect against the tested pathogens and thus Polyclinum madrasensis needs further attention.

\section{Acknowledgement}

Authors are thankful to Dr. V.K. Meenakshi, A.P.C. Mahalaxmi College for Women, Tuticorin for her valuable guidance in collection and identification of ascidians.

\section{References}

1. Alade PI and Irobi ON (1993) Antifungal activities of crude leaf extract of Acalypha wilkesiana. J. Ethnopharmacol. 39, 171-174.

2. Azumi K, Yoshimizu M, Suzuki S, Ezura $Y$ and Yokosawa $H$ (1990) Inhibitory effect of halocyamine, an antimicrobial substance from ascidian hemocytes, on the growth of fish viruses and marine bacteria. Cell. Mol. Life Sci. 46(10), 1066-1068.

3. Bergquist PR and Bedford JJ (1978) The incidence of antibacterial activity in marine demospongiae; Systematic and geographic considerations. Marine Biol. 46 (3), 215221.

4. Biard JF, Guyout S, Roassaki C and Verbist JF (1994) Lepadi- formine, a new marine cytotoxic alkaloid from Clavelina lepadiformis. Tetrahedran Lett., 35, 2691-2694.

5. Carte BK (1996) Biomedical potential of marine natural products. Biosci. 46, 271-286.

6. Collins CH, Lyne PM, Grange JM (1995) Microbiological methods. $7^{\text {th }}$ edn. Butterwort - Heinemann Ltd. Britain. pp175-190.

7. Davidson BS (1993) Ascidians: producers of amino acid derived metabolites. Chem. Rev. 93, 1771-1791.

8. Hugo WB, Russell AB (2004) Pharmaceutical microbiology. $7^{\text {th }}$ edn. London: Black Well Scientific Publication. pp196-201.

9. Kurosoki $F$ and Nishi A (1983) Isolation and antimicrobial activity of the phytoalexin-6-methoxymellein from cultured carrot cells. Phytochem. 22(3), 669-672.

10. Seleghim MHR, Lira SP, Kossuga MH, Batista T, Berlinck RGS and Hajdu E (2007) Antibiotic, cytotoxic and enzyme inhibitory activity of crude extracts from Brazilian marine invertebrates. Brazilian J. Pharmacognosy. 17(3), 287-318.

11. Proksch $P$, Edrada RA and Ebel $R$ (2002) Drugs from the sea-current status and microbiological Implications. Appl. Microbiol. Biotechnol. 59,125-134.

12. Russo GL, Ciarcia G, Presidente E, Siciliano RA and Tosti E (2008) Cytotoxic and apoptogenic activity of a methanolic extract from the marine invertebrate Ciona intestinalis on malignant cell lines. Med. Chem. 4(2), 106109.

Research communication

CIndian Society for Education and Environment (iSee)
"Antibacterial activity of Polyclinum madrasensis" http://www.indjst.org
Natarajan et al. Indian J.Sci.Technol. 